\title{
In vitro fermentation of the rations containing Morinda citrifolia $L$. (Noni) using two types of inoculum
}

\section{Fermentação in vitro de rações contendo Morinda citrifolia L (Noni) com uso de dois tipos de inóculo}

\author{
Luiz Juliano Valério Geron ${ }^{1 *}$; Luiz Eduardo Cantão Veloso²; Sílvia Cristina \\ de Aguiar ${ }^{1}$; Alexandre Lima de Souza ${ }^{3}$; Ilda de Souza Santos'; Raquel Joana \\ Trautmann-Machado ${ }^{5}$; Anderson de Moura Zanine ${ }^{6}$; Rayane Fernandes da Silva ${ }^{1}$; \\ Daniela de Jesus Ferreira ${ }^{6}$; Suellem Fernanda Perosa Zanin ${ }^{7}$
}

\begin{abstract}
The effect of inclusion of Morinda citrifolia L. (Noni) in standardized diets of sheep on in vitro digestibility and parameters fermentation was examined using two different inoculums (ruminal liquid and sheep feces). To determine the nutrients' in vitro digestibility coefficient (IVDC), two sheep were used as inoculum donors. The experimental design was factorial $(4 \times 2)$, with four diets containing different proportions of Noni and two types of inoculum. The different dietary proportions of Noni $(0 \%$, $8 \%, 16 \%$, and $24 \%$ ) did not affect the IVDC of dry matter (DM), organic matter (OM) and crude protein (CP) for both inoculums. The IVDC of neutral detergent fiber (NDF) differed significantly between the inoculums. After in vitro incubation for $24 \mathrm{~h}$, the $\mathrm{pH}$ value of the fermented material differed between the different diets and between the inoculums. Moreover, the concentration of ammoniacal nitrogen was affected by the proportion of Noni and differed between the inoculums after incubation for 24 h. The inclusion of up to $24 \%$ of Noni in standardized rations for ruminants did not affect the $I V D C$ of DM, OM, CP, and NDF. The use of feces as inoculum for in vitro fermentation produced lower $I V D C$ values than those by ruminal liquid. The diet containing $8 \%$ of Noni and fermented with ruminal liquid produced higher $\mathrm{pH}$ values after $24 \mathrm{~h}$ of incubation. Taken together, the different dietary Noni proportions and the different inoculums can alter the concentration of ammoniacal nitrogen of sheep diets after $24 \mathrm{~h}$ in vitro fermentation; however, they seem not to affect the IVDC of the nutrients.
\end{abstract}

Key word: Ammoniacal nitrogen. Feces. Ph. Ruminal liquid.

1 Profs., Universidade do Estado de Mato Grosso, UNEMAT, Pontes e Lacerda, MT, Brasil. E-mail: ljgeron@yahoo.com.br e/ou ljgeron@unemat.br; scaguiar@unemat.br

2 Discentes do Curso de Mestrado, Pós Graduação em Zootecnia, Universidade Federal do Mato Grosso - UFMT, Sinop, MT, Brasil. E-mail: duducantao@hotmail.com

3 Prof., UFMT, Cuiabá, MT, Brasil. E-mail: alexandre@ufmt.br

4 Discentes do Curso de Bacharelado em Zootecnia, Universidade do estado de Mato Grosso - UNEMAT, Pontes e Lacerda, MT, Brasil. E-mail: ildasouza20@hotmail.com

5 Zootecnista do Instituto de Defesa Agropecuária do Estado de Mato Grosso - INDEA-MT, Pontes e Lacerda, MT, Brasil. E-mail: raquel_trautmann@hotmail.com

6 Prof., Universidade Federal do Maranhão, UFMA, Chapadinho -MA, E-mail: anderson.zanine@ibest.com.br

7 Discentes do Curso de Mestrado, Pós Graduação em Ciência Animal, Universidade Federal do Mato Grosso - UFMT, Cuiabá, MT, Brasil. E-mail: suellemfpzanin@gmail.com

* Author for correspondence 


\section{Resumo}

Avaliou-se a inclusão de Morinda citrofolia L (Noni) em rações balanceadas para ovinos sobre o coeficiente de digestibilidade in vitro (CDIV) dos nutrientes e os paramentos da fermentação in vitro com utilização de diferentes inóculos (líquido ruminal e fezes de ovinos). Para a determinação do CDIV dos nutrientes foram utilizados dois ovinos com peso corporal médio de $25+2,0 \mathrm{~kg}$, como doadores de inóculo (líquido ruminal e fezes). O delineamento experimental foi o fatorial 4X2, com quatro teores de inclusão de Noni e dois tipos de inóculo para a determinação do CDIV dos nutrientes. As variáveis estudadas foram submetidas à análise de variância e para os teores de inclusão de Noni procedeu-se análise de regressão a $5 \%$ de probabilidade e para os diferentes inóculos foi realizado teste de Tukey a 5\% de significância. Os diferentes teores de inclusão do Noni $(0 \% ; 8 \% ; 16 \%$ e $24 \%)$ nas rações balanceadas os ovinos não alteraram $(\mathrm{P}>0,05)$ os $\mathrm{CD} I V$ da MS; MO e PB para ambos os inóculos (líquido ruminal e fezes de ovinos). Foi observado que a utilização dos diferentes inóculos propiciou alteração $(\mathrm{P}<0,05)$ no valor do $\mathrm{CDIV}$ da FDN. Os teores de $0 \% ; 8 \% ; 16 \%$ e $24 \%$ de Noni nas rações para ruminantes e os diferentes inóculos (líquido ruminal e fezes de ovinos) propiciaram alterações ( $\mathrm{P}<$ $0,05)$ no valor de $\mathrm{pH}$ do conteúdo fermentado após a incubação in vitro de 24 horas. A inclusão de $0 \%$, $8 \% ; 16 \%$ e $24 \%$ de Noni nas rações de ruminantes e a utilização de inóculo a base de líquido ruminal ou fezes de ovinos propiciaram alterações $(\mathrm{P}<0,05)$ na concentração do nitrogênio amoniacal $(\mathrm{N}-\mathrm{NH} 3)$ do conteúdo fermentado das rações após incubação in vitro de 24 horas. A inclusão de até $24 \%$ de Noni em rações balanceadas para ruminantes não alterou o coeficiente de digestibilidade in vitro da matéria seca, matéria orgânica, proteína bruta e fibra em detergente neutro. A utilização de fezes como inóculo da fermentação in vitro propiciou menor valor em relação à utilização do inóculo líquido ruminal na digestão in vitro. Para o valor de $\mathrm{pH}$ do conteúdo fermentado após 24 horas de incubação a inclusão do $8 \%$ de Noni propiciou maior valor com o inóculo líquido ruminal. Desta maneira, os diferentes teores de Noni e os diferentes inóculos podem alterar a concentração de nitrogênio amoniacal do conteúdo fermentado das rações balanceadas para ovinos após 24 horas de fermentação in vitro, contudo não altera o coeficiente de digestibilidade in vitro dos nutrientes.

Palavras-chave: Ph. Líquido ruminal. Fezes. Nitrogênio amoniacal.

\section{Introduction}

Phytogenic diet additives are substances derived from medicinal plants, and are derived from a wide variety of spices, herbs, and other plant products, such as essential oils, extracts, and oil-resins; these additives may have a positive effect on health and productivity of animals (PERIC et al., 2009; COSTA et al., 2007). A well-known example of phytogenic additives is the Morinda citrifolia L. fruit (termed Noni), which contains several substances that are beneficial for animals, including vitamins $\mathrm{C}$ and $\mathrm{A}$, and phenolic compounds, among others (CORREIA et al., 2011).

The Noni fruit originated from Asia and Oceania and only became commonly known in Brazil several years ago after scientific studies demonstrated its medicinal value. Furthermore, the plant's roots have been used as a dyeing agent for more than
2000 years. Noni thrives in tropical climates, and therefore it developed rapidly in Brazil (WANG et al., 2002; BARBOSA et al., 2017). Recent literature introduced the term "functional foods", which is defined as dietary items containing compounds (which are not necessarily nutrients) that are supposed to promote health or reduce the risk of diseases when consumed in traditional quantities (RAUD, 2008).

According to Sichieri et al. (2000) many food products on the current market are fortified with vitamins and minerals, and are therefore referred to as "functional foods" due to their contents of proteins, fatty acids, beneficial bacteria, fibers, carotenoids, and phenolic substances, among others.

The Noni fruit consists of water to $90 \%$, on average, and the main components of the dry matter are soluble solids, dietary fibers, and proteins 
(COSTA et al., 2013). It also contains several vitamins such as ascorbic acid and provitamin A in relatively high concentrations, and gallic acid equivalent (GAE) of phenolics at a concentration of $216.67 \mathrm{mg} / 100 \mathrm{~g}$ (CORREIA et al., 2011).

Costa et al. (2013) examined Noni pulp, peel, and seed, and found that all fractions showed in vitro antioxidant activity due to the presence of phenolic compounds. Furthermore, Zaidan et al. (2005) observed that Noni exhibited antimicrobial action against five strains of bacteria (Staphylococcus aureus, methicillin-resistant Staphylococcus aureus, Klebsiella pneumoniae, Pseudomonas aeruginosa, and Escherichia coli). Noni leaf extract also showed antimicrobial effects on the gram-positive bacteria $S$. aureus, methicillin-resistant $S$. aureus. According Wang et al. (2002), the antimicrobial effect of Noni extract is mainly due to the presence of anthraquinones and phenolic compounds. These compounds help to fight off infectious bacteria.

Noni pulp contains low lipid concentrations, and is predominantly composed of carbohydrates and other nutrients, but also contains substantial amounts of niacin (vitamin B3), potassium, and iron. The Noni fruit has been shown to contain significant amounts of vitamin A, calcium, and sodium (SILVA et al., 2009). In this regard, the Noni fruit and its co-products may be considered as an alternative "functional food" addition to animal feed in Brazil, as the nutritional characteristics of Noni fit several requirements of ruminant diets.

Currently, the Noni fruit is consumed due to its bactericidal, analgesic, anticongestive, antioxidant, expectorant, anti-inflammatory, astringent, laxative, and immunostimulatory properties (FARIA et al., 2014). According to Palioto et al. (2015), the consumption of Noni by the population of Polynesia was associated with analgesic and antibacterial effects, which supports its use as a functional food.

According to the literature, food digestion can be defined as a process of converting macromolecules into nutrients or into simpler compounds (VAN SOEST, 1994) which can then be absorbed in the gastrointestinal tract. In this regard, digestibility analyses quantify how much of the food can be effectively used by the animal, and reflect its nutritive value, which is expressed as a coefficient of digestibility. This indicates a percentage of each nutrient that can be assimilated by the organism. The coefficient of digestibility of the feed can be influenced by several factors, such as food composition and processing, animal-dependent factors, and nutritional parameters, e.g. energy density and consumption, among others (ALVES et al., 2003).

In general, in vivo digestibility seems to be one of the most accurate techniques for initial food evaluation, as its results are closest to the actual digestibility within the organism; this method is therefore closest to practical applications in vivo (GERON et al., 2008; GERON et al., 2013). Thus, the use of in vitro techniques to predict in vivo digestibility is recommended based on high correlation coefficients (SILVA; QUEIROZ, 2002). This method facilitates comparisons of species, forage cuttings, and food fractions (SILVA; QUEIROZ, 2002).

Thus, an assessment of the dietary value of Noni in ruminant diets is necessary, as this product is a relatively new feed addition. This study aimed to evaluate the inclusion of different proportions of Noni $(0 \%, 8 \%, 16 \%$, and $24 \%)$ and to test its effect on the in vitro digestibility coefficient (IVDC) in diets of sheep, using two types of inoculum (ruminal liquid and sheep feces).

\section{Material and Methods}

The experiment was carried out in the Animal Metabolism Sector (SEMA) and the Laboratory of Food Analysis and Animal Nutrition (LAANA) of the University Campus of Pontes and Lacerda, State University of Mato Grosso - UNEMAT.

The basic diet used for experimental Noni addition consisted of corn silage, milled corn, and soybean meal. Dehydrated Noni was added in DM proportions of $0 \%, 8 \%, 16 \%$, and $24 \%$. 
Noni fruits originated from non-commercial plantations in the municipality of Pontes and Lacerda (in the southwest region of the state of Mato Grosso) and were harvested from May to June 2015. The fruits were processed using a $10 \mathrm{~mm}$ sieve crusher, and were then sun-dried for about 96 $\mathrm{h}$ on a plastic canvas in layers of approximately 5 cm thickness.

The experimental design was a factorial $(4 \times$ 2 ), with four experimental diets and two different inoculums (rumen liquid and sheep feces).

For the in vitro digestion of nutrients, five technical replicates were performed. For this, fermentation batteries were used, in each of which three tubes of each experimental diet were placed.
The diets were incubated with one of the inoculum, which is an adaption of the in vitro digestibility one-stage method for a 24-h in vitro fermentation by from Smith et al. (2010).

The bromatological composition of the foods (Table 1) and of the diets used in the in vitro digestion assay is shown in Table 2. Two sheep of an average body weight of $25 \pm 2.0 \mathrm{~kg}$ were kept in a metabolism cage as inoculum donors (ruminal bacteria). Fifteen days before the start of the experimental period the sheep were treated against intestinal parasites with Ivermectin. Ruminal liquid samples were collected using an esophageal probe and a vacuum pump, as described by Zeoula et al. (2003).

Table 1. Bromatological composition of experimental foods.

\begin{tabular}{lccccccc}
\hline Foods & \multicolumn{7}{c}{ \% of nutrients expressed in DM } \\
\hline & \% DM & OM & CP & EE & NDF & ${ }^{1}$ TDN & ${ }^{1}$ GAE of phenolics total $100^{-1} \mathrm{~g}$ \\
\hline CS & 24.00 & 95.05 & 8.42 & 3.02 & 54.99 & 63.04 & - \\
CG & 89.95 & 97.83 & 10.14 & 4.23 & 15.46 & 85.30 & - \\
SM & 90.73 & 92.36 & 49.76 & 1.30 & 16.91 & 84.22 & - \\
Noni & 86.92 & 92.76 & 7.00 & 1.02 & 25.43 & 78.50 & 0.267 \\
Urea & 100.00 & 0.00 & 280.00 & 0.00 & 0.00 & 0.00 & - \\
\hline
\end{tabular}

CS: corn silage; CG: corn grain; SM: soybean meal; DM: dry matter; OM: organic matter; CP: crude protein; EE: ethereal extract; NDF: fiber in neutral detergent; TDN: total digestive nutrients. GAE: gallic acid equivalent. ${ }^{1}$ Valadares Filho et al. (2006) and Correia et al. (2011).

The experimental diets were standardized to a crude protein content of $13.5 \%$ and $70.0 \%$ of total digestible nutrients, according to NRC (2007), which should produce an average gain of 100 to 150 $\mathrm{g}$ per animal per day. The donor animals were fed with a diet consisting of $60 \%$ bulk feed (corn silage) and $40 \%$ concentrate, and no Noni addition.

The animals were fed twice per day (7:00 a.m. and 5:00 p.m.). Diet consumption was controlled to produce an amount of $10 \%$ of leftovers. The sheep were allowed to adjust to this feeding scheme for 15 days. Water was provided ad libitum, and $5 \mathrm{~g}$ of a mineral mixture was added to each supply.
On the day of inoculum collection the animals were fed at 7:00 a.m. and after $2 \mathrm{~h}$, approximately $0.6 \mathrm{~L}$ of ruminal liquid was collected from each animal. After collection, the liquid was filtered through a cotton filter and incubated in a bottle containing $\mathrm{CO}_{2}$. An amount of $0.5 \mathrm{~L}$ of the filtered liquid of each animal was used to produce the inoculums for experimental in vitro incubation. Feces were collected from the rectum $30 \mathrm{~min}$ after ruminal liquid collection (according to ALCALDE et al., 2001), and stored in a buffer at a 1:1 dilution ratio. 
Artificial saliva was prepared using 300 $\mathrm{mL}$ McDougall buffer solution $\left(\mathrm{NaHCO}_{3}\right.$, $\mathrm{Na}_{2} \mathrm{HPO}_{4} \cdot 7 \mathrm{H}_{2} \mathrm{O}, \mathrm{KCl}, \mathrm{NaCl}, \mathrm{MgSO}_{4} \cdot 7 \mathrm{H}_{2} \mathrm{O}, \mathrm{CaCl}_{2}$; McDougall, 1948), $5 \mathrm{~mL}$ urea solution (5.5 g per $100 \mathrm{~mL}$ of distilled $\mathrm{H}_{2} \mathrm{O}$ ), and $5 \mathrm{~mL}$ glucose solution
( $5.5 \mathrm{~g}$ per $100 \mathrm{~mL}$ of distilled $\mathrm{H}_{2} \mathrm{O}$ ). The mixture was prepared on the day before in vitro incubation and stored at $39^{\circ} \mathrm{C}$ until use. The $\mathrm{pH}$ of the artificial saliva was adjusted to $6.8-7.0$, by adding $\mathrm{CO}_{2}$.

Table 2. Percentage and bromatological composition of experimental rations evaluated to obtain the in vitro digestibility coefficient (IVDC) of dry matter (DM).

\begin{tabular}{lcccc}
\hline \multirow{2}{*}{\multicolumn{1}{c}{ Foods }} & \multicolumn{4}{c}{ Proportions of Noni in experimental diets } \\
\cline { 2 - 5 } & $0 \%$ & $8 \%$ & $16 \%$ & $24 \%$ \\
\hline Corn silage & 60,0 & 60.0 & 60.0 & 60.0 \\
Corn grain & 32.0 & 23.5 & 14.5 & 5.5 \\
Soybean meal & 7.5 & 8.0 & 9.0 & 10.0 \\
Noni & 0.0 & 8.0 & 16.0 & 24.0 \\
Urea & 0.5 & 0.5 & 0.5 & 0.5 \\
Total & 100.0 & 100.0 & 100.0 & 100.0 \\
\hline Bromatological composition of experimental rations evaluated in in vitro digestion & & \\
\hline Dry matter (DM) & 50.38 & 50.53 & 50.68 & 50.83 \\
Organic matter (OM) \% & 95.26 & 94.83 & 94.37 & 93.91 \\
Crude protein (CP) \% & 13.43 & 13.38 & 13.52 & 13.67 \\
Ethereal extract (EE) \% & 3.26 & 2.99 & 2.71 & 2.42 \\
Fiber in neutral detergent (NDF) \% & 39.21 & 40.02 & 40.83 & 41.64 \\
GAE of phenolics total $100^{-1} \mathrm{~g}$ & 0.00 & 0.02 & 0.04 & 0.06 \\
total digestive nutrients (TDN) \% & 71.44 & 70.89 & 70.33 & 69.80 \\
\hline
\end{tabular}

The four experiments diets were aliquoted into tubes ( $0.5 \mathrm{~g}$ each), to which $37.5 \mathrm{~mL}$ of the artificial saliva solution and $12.5 \mathrm{~mL}$ of the respective inoculum was added, following the method of Smith et al. (2010). Remaining air in the tubes was replaced by $\mathrm{CO}_{2}$, after which the tubes were sealed using rubber stoppers with Bunsen valves.

After this, the diet treatments were left to incubate for $24 \mathrm{~h}$ in a micro-processed digital water bath with an automatic heater (Dubnoff-type, mod. Q226 M1, Quimis), at a temperature of $39.2{ }^{\circ} \mathrm{C}$ and constant stirring.

Following incubation, the fermentation was stopped by placing the tubes in a container containing crushed ice, for $10 \mathrm{~min}$. The contents of the tubes were then filtered on quantitative filter paper (black strip, $15 \mathrm{~cm}$ diameter for rapid filtration of thick and gelatinous precipitates), and the filter contents were oven-dried at $65{ }^{\circ} \mathrm{C}$ for $72 \mathrm{~h}$. After this, the filter contents were placed in a desiccator for subsequent weighing. The filtered liquid was retained for ammoniacal nitrogen content $\left(\mathrm{N}-\mathrm{NH}_{3}\right)$ analysis.

The IVDC of the DM and of the other diet components was determined using the following formula:

IVDC of DM = sample weight (g DM) - [ weight of the residue ( $\mathrm{g} D M)$ - weight of the filter paper ( $g$ $\mathrm{DM})$ ] / sample weight $(\mathrm{g} \mathrm{DM}) \times 100$, as proposed by Silva \& Queiroz (2002). 
After filtration, the $\mathrm{pH}$ of the fermented content was measured using a bench top digital $\mathrm{pH}$ meter.

Sulfuric acid $(0.2 \mathrm{~mL})$ was added to $20 \mathrm{~mL}$ aliquots of the filtrates (1:1) for acidification of the medium and to stop the fermentation process. These samples were then used to measure the concentrations of $\mathrm{N}^{-\mathrm{NH}_{3}}$ by distillation with potassium hydroxide $(\mathrm{KOH}, 2 \mathrm{~mol} / \mathrm{L})$ according to Preston (1995).

Corn silage samples were oven-dried at $55 \pm 5$ ${ }^{\circ} \mathrm{C}$ for $72 \mathrm{~h}$, after which they were shredded and subsequently sieved (1 mm mesh).

The experimental diets were analyzed for their nitrogen content using a semi-micro Kjeldahl method; mineral matter (MM), organic matter $(\mathrm{OM})$, and ethereal extract (EE) were determined according to Silva \& Queiroz (2002), and neutral detergent fiber (NDF) content was measured as recommended by Van Soest et al. (1991) without the use of sulfite and without correcting the values of NDF and acid detergent fiber regarding the mineral content of the fiber.

The $I V \mathrm{DC}, \mathrm{pH}$, and $\mathrm{N}-\mathrm{NH}_{3}$ values were subjected to an analysis of variance, using SAEG software
(UFV, 1997), and a post hoc Tukey's test; statistical significance is reported at $p<0.05$. To analyze the different Noni proportions, a regression analysis at a significance level of 5\% was performed.

\section{Results and Discussion}

The four experimental diets containing different proportions of Noni $(0 \%, 8 \%, 16 \%$, and $24 \%)$ did not differ significantly regarding the IVDC of DM, $\mathrm{OM}$, and $\mathrm{CP}$ regarding both inoculums (Table 3). The following mean IVDC values of DM, OM, and $\mathrm{CP}$ were observed in diets inoculated with ruminal liquid: $62.41 \%, 62.87 \%$, and $59.26 \%$, respectively; the corresponding values of the fecesinoculated diets were $60.92 \%, 60.03 \%$, and $58.03 \%$, respectively. Inclusion of up to $24 \%$ of Noni in the experimental diets produced a total phenolic compound concentration of $0.06 \mathrm{~g}$ of GAE/100 $\mathrm{g}$ (Table 2). This amount of phenolic compounds did not likely alter the microbiotic activity in either inoculum. The expected positive associative effect due to the mixing of different ingredients in the experimental diets was not observed, which may be due to the ratio of bulk feed to concentrate (60:40).

Table 3. In vitro digestibility coefficient values (IVDC) for the different inoculums (rumen liquid and sheep feces) in balanced rations for sheep with different proportions of Noni.

\begin{tabular}{|c|c|c|c|c|c|c|c|}
\hline Variable & Inoculum & Pro & ons of $\mathrm{Nc}$ & experim & diets & Regression & $\% \mathrm{CV}$ \\
\hline & & $0 \%$ & $8 \%$ & $16 \%$ & $24 \%$ & & \\
\hline$I V \mathrm{DC} \mathrm{DM}$ & Rum. Liq. & 64.53 & 62.67 & 61.67 & 6075 & $\hat{\mathrm{Y}}=62.41 \mathrm{a}$ & 10.48 \\
\hline$I V \mathrm{DC} \mathrm{DM}$ & Feces & 57.37 & 63.98 & 62.24 & 60.10 & $\hat{\mathrm{Y}}=60.92 \mathrm{a}$ & 10.78 \\
\hline$I V \mathrm{DC} \mathrm{OM}$ & Rum. Liq. & 65.29 & 63.39 & 62.30 & 60.50 & $\hat{\mathrm{Y}}=62.87 \mathrm{a}$ & 8.06 \\
\hline$I V \mathrm{DC} \mathrm{OM}$ & Feces & 57.86 & 64.00 & 62.09 & 59.77 & $\hat{\mathrm{Y}}=60.93 \mathrm{a}$ & 8.55 \\
\hline$I V \mathrm{DC} C \mathrm{CP}$ & Rum. Liq. & 58.95 & 60.49 & 59.95 & 57.64 & $\hat{\mathrm{Y}}=59.26 \mathrm{a}$ & 8.76 \\
\hline$I V \mathrm{DC} C \mathrm{CP}$ & Feces & 57.63 & 59.21 & 58.34 & 56.92 & $\hat{\mathrm{Y}}=58.03 \mathrm{a}$ & 8.13 \\
\hline$I V \mathrm{DC} \mathrm{NDF}$ & Rum. Liq. & $48.82 \mathrm{~b}$ & $46.04 \mathrm{a}$ & $48.97 \mathrm{~b}$ & $47.83 \mathrm{~b}$ & $\hat{\mathrm{Y}}=47.92$ & 10.47 \\
\hline$I V \mathrm{DC} \mathrm{NDF}$ & Feces & $42.17 \mathrm{a}$ & $40.87 \mathrm{a}$ & $41.42 \mathrm{a}$ & $39.71 \mathrm{a}$ & $\hat{\mathrm{Y}}=41.04$ & 11.02 \\
\hline
\end{tabular}

Rum. Liq.: rumen liquid - inoculum. CV: coefficient of variation; DM: dry matter OM: organic matter; CP: crude protein; NDF: fiber in neutral detergent. 
Thus, of the addition of Noni did not did not seem to affect the ruminal environment significantly, as the IVDC values of $\mathrm{DM}, \mathrm{OM}$, and $\mathrm{CP}$ showed no difference between the diets. However, Caixeta (2016) conducted a study to evaluate the use of Noni extract on degradability (using the fractionation suggested by the Cornell System of ruminant diets) and observed that 5 and $15 \mathrm{~g}$ of crude Noni extract per day and animal resulted in better values of the Fraction A + B1, and higher gas production, which indicates an improvement of the ruminal environment. No comparable effect on the ruminal environment, however, was observed in the present study.

Furthermore, Noni contained $7.00 \%$ CP (Table 1 ), and the experimental diets were standardized to $13.5 \% \mathrm{CP}$ in an isoproteic form, according to NRC (2007). This may have led to the similar IVDC values of $\mathrm{CP}$ of the experimental diets (Table 3). However, previous studies (GERON et al., 2013, CAVALCANTE et al., 2005) showed that the in vitro digestibility of diets with high $\mathrm{CP}$ contents (above 16\%) significantly affected the CP IVDC due to higher proportions of protein available for ruminal fermentation.

In the present study, the different inoculums did not differ regarding their effect on in vitro fermentation. This finding suggests that both inoculums can be used to determine the digestibility of DM, OM, and CP. It is worth noting that the method of using sheep feces as an inoculum for in vitro digestion is substantially less invasive and less stressful for the donor animals, and is also more practical and less time intensive. These factors are considerable advantages regarding animal welfare and applicability.

However, diets treated with ruminal liquid seemed to produce a decreasing trend regarding DM $I V D C$, with the $24 \%$ Noni diet showing a DM IVDC which was $5.86 \%$ below that of the diet without Noni. In contrast, the DM IVDC value of the $24 \%$ Noni diet was $4.54 \%$ above that of the diet without Noni, when feces were used as inoculum. This result indicates that the use of feces as inoculum for DM $I V \mathrm{DC}$ measurement may produce larger variance, however, no significant difference in variances was observed. Further studies would be needed to confirm feces as a fermentation inoculum for IVDC assessments.

Regarding the CP IVDC, both inoculums produced the same trends in the different experimental diets, confirming that feces can be used as a fermentation inoculum to replace ruminal liquid in in vitro digestibility assays, using the method adapted by Smith et al. (2010).

The IVDC of NDF in the experimental diets did not differ significantly between the two inoculums (Table 3). The mean NDF IVDC values were $47.92 \%$ (ruminal liquid) and $41.04 \%$ (sheep feces). However, regarding the different Noni proportions, ruminal liquid produced significantly higher NDF IVCD values in the diets containing $0 \%, 16 \%$, and $24 \%$ Noni, than in the corresponding diets inoculated with feces (Table 3 ). The diet containing $8 \%$ Noni, however, did not produce a significant difference between the two inoculums. This finding suggests that the activity of fibrinolytic bacteria is higher in ruminal liquid than in feces, which may be due to the more favorable environment in the inoculum itself, as temperature, $\mathrm{pH}$, humidity, and osmolarity in the rumen are more suitable for these bacteria than in feces.

The $\mathrm{pH}$ after in vitro fermentation was significantly affected by diet composition and inoculum type (Table 4). For the ruminal liquid inoculum, the $\mathrm{pH}$ of the fermented content of Noni-containing diets followed a quadratic function (Figure 1A). The $\mathrm{pH}$ of the $8 \%$ Noni diet was estimated at 7.55. The maximum $\mathrm{pH}$ of the experimental diets inoculated with ruminal liquid was 7.53 , in the $16 \%$ Noni diet (Table 4). Diets inoculated with sheep feces produced a significant, linear increase of $\mathrm{pH}$ (Figure 1B). This indicates that diets containing Noni may affect the ruminal environment by reducing fermentation activity and increasing the $\mathrm{pH}$. Moreover, the $\mathrm{pH}$ of diets fermented with sheep feces indicated a reduction of microbial activity in the rumen, as a larger number of bacteria should have stabilized or reduced the $\mathrm{pH}$. 
Table 4. $\mathrm{pH}$ values and concentration of ammoniacal nitrogen $\left(\mathrm{N}_{-} \mathrm{NH}_{3}\right) \mathrm{mg} 100 \mathrm{~mL}^{-1}$ of the fermented content after 24 hours incubation in vitro with ruminal liquid and sheep faces of different experimental rations containing different proportions of Noni.

\begin{tabular}{|c|c|c|c|c|c|c|c|}
\hline Variable & Inoculum & Propo & of Non & xperime & diets & Regression & $\% \mathrm{CV}$ \\
\hline & & $0 \%$ & $8 \%$ & $16 \%$ & $24 \%$ & & \\
\hline $\mathrm{pH}$ & Rum. Liq. & 7.49 & 7.50 & 7.53 & 7.21 & $1 *$ & 4.74 \\
\hline $\mathrm{pH}$ & Feces & 7.52 & 7.65 & 7.67 & 7.71 & $2 *$ & 4.89 \\
\hline $\mathrm{N}^{-N_{3}} \mathrm{mg} 100 \mathrm{~mL}^{-1}$ & Rum. Liq. & 60.73 & 66.33 & 79.63 & 64.05 & $3 *$ & 27.02 \\
\hline $\mathrm{N}^{-N_{3}} \mathrm{mg} 100 \mathrm{~mL}^{-1}$ & Feces & 62.30 & 62.65 & 81.20 & 54.60 & $4 *$ & 29.34 \\
\hline
\end{tabular}

Rum. Liq.: rumen liquid - inoculum. CV: coefficient of variation.

Figure 1. $\mathrm{pH}$ values of rations containing different proportions of Noni fermented with ruminal liquid - RL (A) and sheep feces (B) during 24 hours of in vitro incubation.
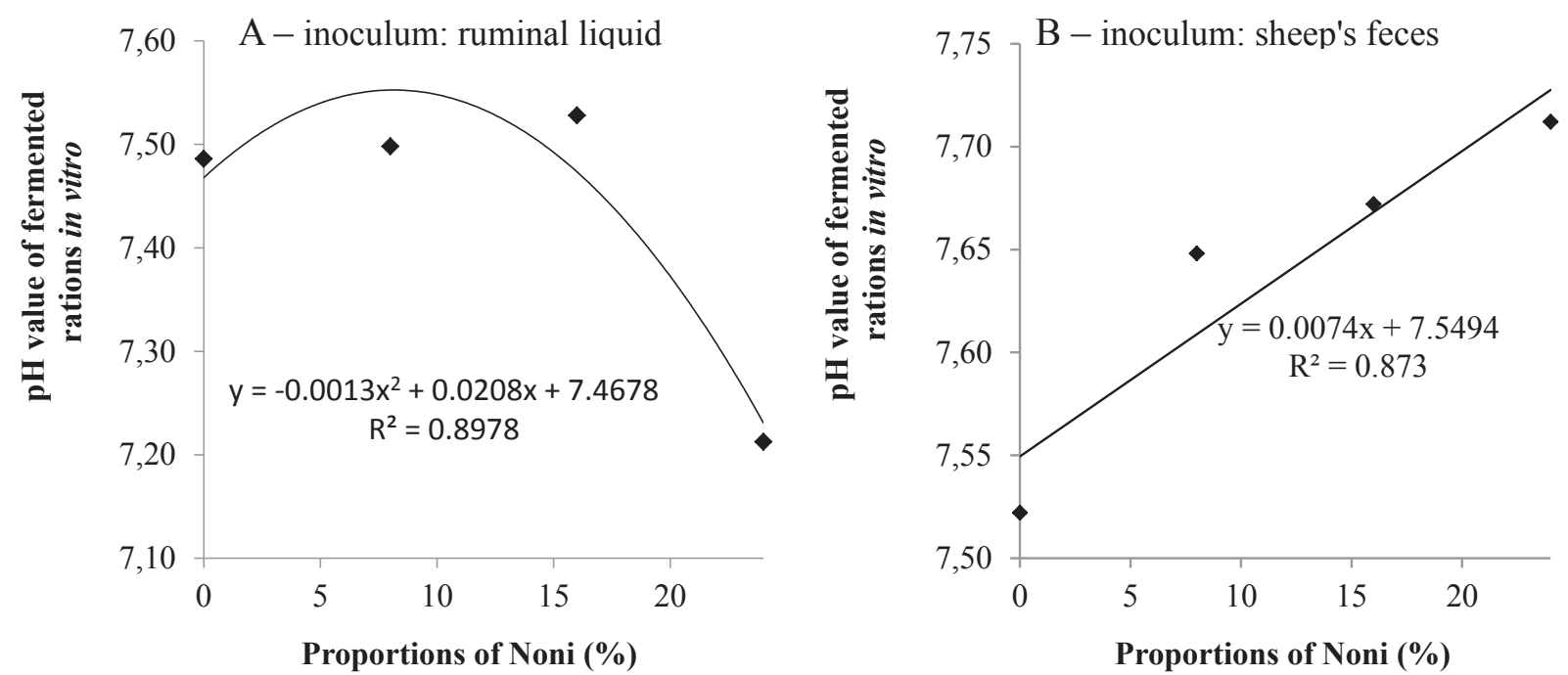

The concentration of $\mathrm{N}_{-} \mathrm{NH}_{3}$ was significantly affected by diet composition and type of inoculum (Table 4). A significant, quadratic function of the $\mathrm{N}-\mathrm{NH}_{3}$ concentrations were observed in diets treated with ruminal liquid inoculum $(\mathrm{P}<0.05)$. The calculated maximum concentration of N-NH3 was $74.35 \mathrm{mg} / 100 \mathrm{~mL}$, in a diet with $13.7 \%$ Noni fermented with ruminal liquid (Figure 2A). Feces-

inoculated diets also produced a significant, quadratic function that differed from the above regarding its maximum (Figure 2B). The calculated maximum $\mathrm{N}-\mathrm{NH} 3$ concentration after feces-inoculation was $73.61 \mathrm{mg} / 100 \mathrm{~mL}$, in a diet containing $11.7 \%$ Noni. The lowest $\mathrm{N}_{-} \mathrm{NH}_{3}$ concentration after fermentation with feces was $54.60 \mathrm{mg} / 100 \mathrm{~mL}$, in the $24 \%$ Noni diet. 
Figure 2. Ammoniacal nitrogen concentration $\left(\mathrm{N}_{-} \mathrm{NH}_{3} \mathrm{mg} / 100 \mathrm{~mL}\right)$ of rations containing different proportions of Noni fermented with ruminal liquid - RL (A) and sheep feces (B) during 24 hours of in vitro incubation.

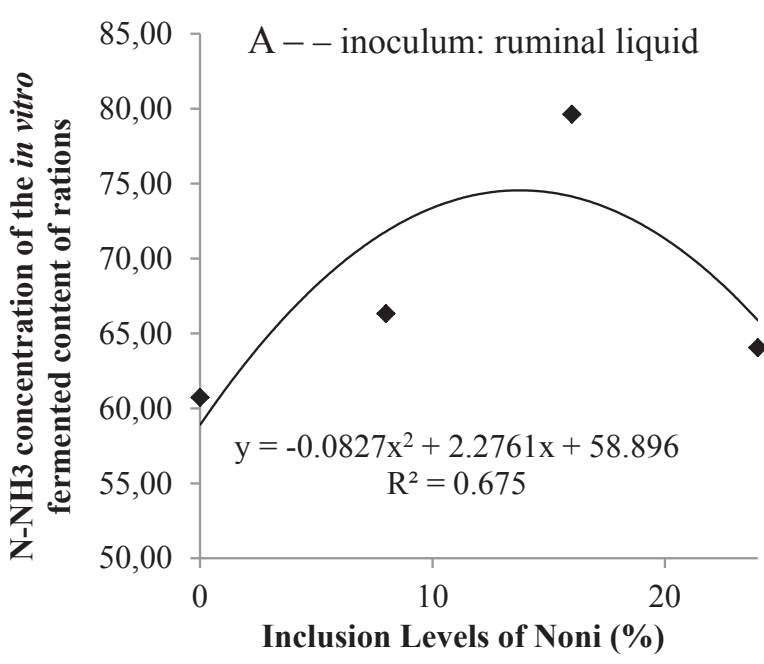

\section{Conclusions}

Noni in ruminant diets seems to affect the fermentation environment. Using sheep feces as an in vitro fermentation inoculum, bacterial activity was lower, compared to inoculation with ruminal liquid, which led to lower ammoniacal nitrogen concentrations.

Inclusion of up to $24 \%$ Noni in standardized ruminant diets did not affect the IVDC of DM, OM, $\mathrm{CP}$, and NDF. The use of feces as an inoculum for in vitro fermentation produces higher variance of nutrient IVDC, compared to ruminal liquid.

\section{Acknowledgements}

The authors thank the Foundation for Research Support of the State of Mato Grosso (FAPEMAT) for granting scholarships for scientific initiation to the students of the Bachelor's Degree in Animal Science.

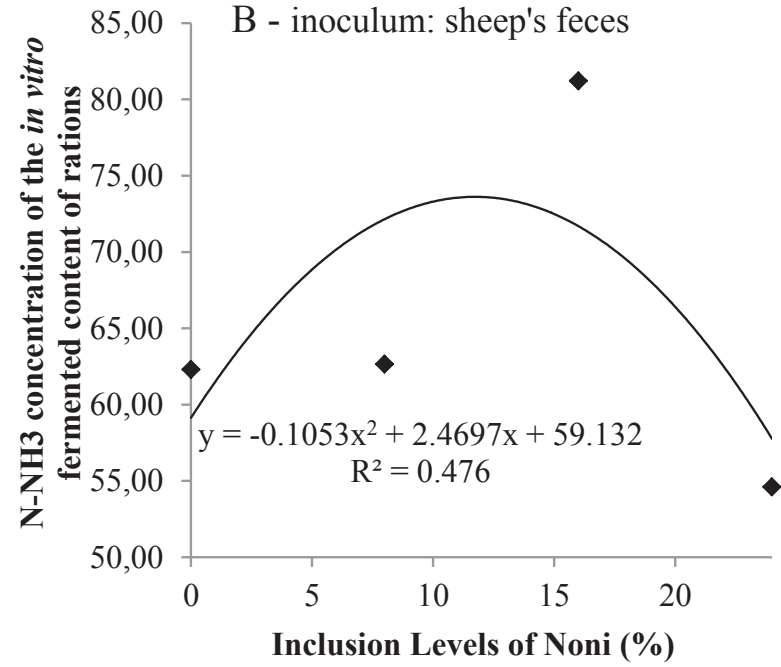

\section{References}

ALCALDE, C. R.; MACHADO, R. M.; SANTOS, G. T.; PICOLLI, R.; JOBIM, C. C. Digestibilidade in vitro de alimentos com inóculos de líquido de rúmen ou de fezes de bovinos. Acta Scientiarum. Animal Science, Maringá, v. 24, n. 4, p. 917-921, 2001.

ALVES. S. K.; CARVALHO. F. F. R.; VÉRAS. A. S. C.; FERREIRA, M. A.; COSTA, R. G.; SANTOS, E. P.; FREITAS, C. R. G.; SANTOS JUNIOR, C. M. Níveis de Energia em Dietas para Ovinos Santa Inês: Digestibilidade Aparente. Revista Brasileira de Zootecnia, Viçosa, v. 32, n. 6, p. 1962-1968. 2003.

BARBOSA, A. F.; COSTA, I. C. M.; ZUCOLOTTO, S. M.; GIORDANI, R. B. Morinda citrifolia: fatos e riscos sobre o uso do noni. Revista Fitos, Rio de Janeiro, v. 11, n. 2, p. 119-249, 2017.

CAIXETA, L. F. S. Extratos vegetais de Morinda citrofolia $L$ (Noni) como aditivo alimentar para ruminantes. Dissertação (Mestrado em Zootecnia) - Instituto Federal Goiano, Campus Rio Verde, 2016.

CAVALCANTE, M. A. B.; PEREIRA, O. G.; VALADARES FILHO, S. C.; RIBEIRO, K. G.; CHIzzOTTI, F. H. M.; PEREIRA, D. H. Níveis de proteína bruta em dietas para bovinos de corte: consumo e digestibilidade total e parcial dos nutrientes. Revista Brasileira de Zootecnia, Viçosa, v. 34, n. 6, p. 22002208, 2005. Suplemento 1. 
CORREIA, A. A. S.; GONZAGA, M. L. C.; AQUINO, A. C.; SOUZA, P. H. M.; FIGUEIREDO, R. W.; MAIA, G. A. Caracterização química e fisioquímica da polpa do noni (Morinda citrifolia) cultivado no estado do Ceará. Alimentos e Nutrição, Fortaleza, v. 22, n. 4, p. 609-615, 2011.

COSTA, A. B.; OLIVEIRA, A. M. C.; SILVA, A. M. O.; MANCINI FILHO, J.; LIMA, A. Atividade antioxidante da polpa, casca e semente do Noni (Morinda citrofolia L). Revista Brasileira de Fruticultura, Jaboticabal, v. 35, n. 2, p. 345-354, 2013.

COSTA, L. B.; TSE, M. L. P.; MIYADA, V. S. Extratos vegetais como alternativas aos antimicrobianos promotores de crescimento para leitões recém desmamados. Revista Brasileira de Zootecnia, Viçosa, v. 36, n. 3, p. 589-595, 2007.

FARIA, W. C. S.; BETT, S. C.; SANTOS, C. G. B.; BRASIL, A. S.; GAUTO, R. F.; BESERRA, A. M. S. S.; OLIVEIRA, A. P. Caracterização físico-química e análise fitoquímica preliminar do fruto Noni (Morinda citrofolia L) produzido na cidade de Cuiabá-a-MT. Revista Brasileira de Tecnologia Agroindustrial, Ponta Grosso, v. 8, n. 1, p. 1208-1215, 2014.

GERON, L. J. V.; MEXIA, A. A.; CRISTO, R. L.; GARCIA, J.; CABRAL, L. S.; TRAUTAMANN, R. J.; MARTINS, O. S.; ZEOULA; L. M. Consumo, digestibilidade dos nutrientes e características ruminais de cordeiros alimentados com níveis crescentes de concentrado em ambiente tropical no Vale do Alto Guaporé - MT. Semina: Ciências Agrárias, Londrina, v. 34, n. 5, p. 2497-2510, 2013.

GERON, L. J. V.; ZEOULA, L. M.; ERKEL, J. A.; PRADO, I. N.; JONKER, R. C.; GUIMARÃES, K. C. Coeficiente de digestibilidade e características ruminais de bovinos alimentados com rações contendo resíduo de cervejaria fermentado. Revista Brasileira de Zootecnia, Viçosa, v. 37, n. 9, p. 1685-1695, 2008.

McDOUGALL, E. I. Studies on ruminant saliva. 1- The composition and output of sheep's saliva. Biochemistry Journal, Nashville, v. 43, n. 1, p. 99-109, 1948.

NATIONAL RESEARCH COUNCIL - NRC. Nutrient requirements of small ruminants: sheep, goats, cervids, and new world camelids. Washington, D.C.: National Academy Press, 2007. 384 p.

PALIOTO, G. F.; SILVA, C. F. G.; MENDES, M. P.; ALMEIDA, V. V.; ROCHA, C. L. M. S. C.; TONIN, L. T. D. Composição centesimal, compostos bioativos e atividade antioxidante de frutos de Morinda citrifolia L (noni) cultivados no Paraná. Revista Brasileira de Plantas Medicinais, Campinas, v. 17, n. 1, p. 59-66, 2015.
PERIC, L.; ZIKIC, D.; LULIC, M. Aplication of alternative of growth promoters in broiler production. Biotechnology in Animal Husbandry, London, v. 25, n. 5-6, p. 387-397, 2009.

PRESTON, T. R. Biological and chemical analytical methods. In: PRESTON, T. R. Tropical animal feeding: a manual for research workers. Rome: FAO, 1995. p. 191264.

RAUD, C. Os alimentos funcionais: a nova fronteira da indústria alimentar análise das estratégias da Danone e da Nestlé no mercado Brasileiro de iogurtes. Revista Sociologia Política, Curitiba, v. 16, n. 31, p. 85-100, 2008.

SICHIERI, R.; COITINHO, D. C.; MONTEIRO, J. B.; COUTINHO, W. F. Recomendações de alimentação e nutrição saudável para a população Brasileira. Arquivo Brasileiro de Endocrinologia e Metabolismo, São Paulo, v. 44, n. 3, p. 227-232, 2000.

SILVA, D. J.; QUEIROZ, A. C. Análise de alimentos: métodos químicos e biológicos. 3. ed. Viçosa Universidade Federal de Viçosa, 2002. 235 p.

SILVA, L. R.; MEDEIROS, P. V. Q.; LEITE, G. A.; SILVA, K. J. P.; SOUSA, J. A. Caracterização física do fruto de Noni (Morinda Citrifolia L). Horticultura Brasileira, Vitória da Conquista, v. 27, n. 2, p. 267-271, 2009.

SMITH, D. R.; DILORENZO, N.; LEIBOVICH, J.; QUINN, M. J.; HOMM, J. W.; GALYEAN, M. L. Effects of sulfur and monensin concentrations on in vitro dry matter disappearance, hydrogen sulfide production, and volatile fatty acid concentrations in batch culture ruminal fermentations. Jornal of Animal Science, Champaign, v. 88, n. 1, p. 1503-1512, 2010.

UNIVERSIDADE FEDERAL DE VISOÇA - UFV. Manual de utilização do programa SAEG: sistema de análise estatística e genéticas. Viçosa: Universidade Estadual de Viçosa, 1997.

VAN SOEST, P. J. Nutritional ecology of the ruminant. Comstock Publ. Assoc. Ithaca, 1994. 476 p.

VAN SOEST, P. J.; ROBERTSON, J. B.; LEWIS, B. A. Methods for dietary fiber, neutral detergent fiber, and nonstarch polysaccharides in relation to animal nutrition. Journal of Dairy Science, Savoy, v. 74, n. 12, p. 35833597, 1991.

WANG, M. Y.; WEST, B. J.; JENSEN, C. J.; NOWICKI, D.; SU, C. H.; PALU, A.; ANDERSON, G. Morinda citrofolia (Noni): a literature review and recent advances in noni research. Acta Pharmacologica Sinica, Shangkay, v. 23, n. 12, p. 1127-1141, 2002. 
ZAIDAN, M. R. S.; NOOR RAIN, A.; BADRUL, A. R.; ADLIN, A.; NORAZAH, A.; ZAKIAH, I. In vitro screening of five local medicinal plants for antibacterial activity using disc diffusion method. Tropical Biomedicine, Kuala Lumpur, v. 22, n. 2, p. 165-170, 2005.

ZEOULA, L. M.; CALDAS NETO, S. F.; GERON, L. J. V.; MAEDA, E. M.; PRADO, I. N.; DIAN, P. H. M. Substituição do milho pela farinha de varredura de mandioca (Manihot esculenta, Crantz) em rações de ovinos: consumo, digestibilidade, balanços de nitrogênio e energia e parâmetros ruminais. Revista Brasileira de Zootecnia, Viçosa, v. 32, n. 2, p. 491-502, 2003. 
